\title{
Compensation for Occupational Diseases and the Importance of Prevention: A Law and Economics Perspective
}

\author{
Citation for published version (APA):
}

Faure, M. G. (2007). Compensation for Occupational Diseases and the Importance of Prevention: A Law and Economics Perspective. European Journal of Social Security, 9, 127-168. https://doi.org/10.1177/138826270700900202

Document status and date:

Published: 01/01/2007

DOI:

10.1177/138826270700900202

Document Version:

Publisher's PDF, also known as Version of record

Document license:

Taverne

Please check the document version of this publication:

- A submitted manuscript is the version of the article upon submission and before peer-review. There can be important differences between the submitted version and the official published version of record.

People interested in the research are advised to contact the author for the final version of the publication, or visit the DOI to the publisher's website.

- The final author version and the galley proof are versions of the publication after peer review.

- The final published version features the final layout of the paper including the volume, issue and page numbers.

Link to publication

\footnotetext{
General rights rights.

- You may freely distribute the URL identifying the publication in the public portal. please follow below link for the End User Agreement:

www.umlib.nl/taverne-license

Take down policy

If you believe that this document breaches copyright please contact us at:

repository@maastrichtuniversity.nl

providing details and we will investigate your claim.
}

Copyright and moral rights for the publications made accessible in the public portal are retained by the authors and/or other copyright owners and it is a condition of accessing publications that users recognise and abide by the legal requirements associated with these

- Users may download and print one copy of any publication from the public portal for the purpose of private study or research.

- You may not further distribute the material or use it for any profit-making activity or commercial gain

If the publication is distributed under the terms of Article $25 \mathrm{fa}$ of the Dutch Copyright Act, indicated by the "Taverne" license above, 


\title{
COMPENSATION FOR OCCUPATIONAL DISEASES AND THE IMPORTANCE OF PREVENTITION: A LAW AND ECONOMICS PERSPECTIVE
}

\author{
Michael G. Faure*
}

\begin{abstract}
This paper deals with possible compensation mechanisms for damage caused by occupational diseases. Specific attention is paid to the potential influence of these compensation mechanisms on prevention of work related incidents. The economic analysis oflaw is used to pay attention to liability and liability insurance whereby both the preventive effects of liability and liability insurance are discussed as well as their capacity to compensate. Attention is equally paid to social security, compensation funds and first party as well as direct insurance schemes. Some empirical evidence concerning the effectiveness of various compensation mechanisms as far as the prevention of occupational diseases is concerned is also discussed.
\end{abstract}

Keywords: prevention; compensation; occupational diseases; law and economics; tort law; liability insurance; occupational hazards; compensation funds; first party insurance; direct insurance

\section{INTRODUCTION}

This paper addresses the possible compensation techniques for damages caused by occupational diseases and the potential influence these compensation techniques

Prof. Dr. Michael Faure is Academic Director of METRO (the Institute for Transnational Legal Research) at Maastricht University. Address: P.O. Box 6166200, MD Maastricht, The Netherlands; Tel.: +31 43 3883028; Fax: +31 43325 9091; E-mail: Michael.Faure@FACBURFDR.unimaas.nl. He would like to acknowledge his gratitude to the participants in the $7^{\text {th }}$ International Congress on Work Injuries Prevention, Rehabilitation and Compensation (Work Congress 7, Hong Kong, 28 June 2006), to two anonymous referees for useful comments on an earlier version of this paper, and to Niels Karssen for research assistance. 
may have on prevention. Today many legal systems follow different models as far as compensation for occupational diseases is concerned. In some legal systems, compensation mainly takes place through various kinds of social security arrangements whereby, provided that the statutory conditions are met, more or less generous amounts of compensation are awarded. Other legal systems primarily rely on private insurance markets, where different types of insurance models (first party or liability insurance) can be followed. These models are found in the special social insurance schemes for eleven occupational accidents and diseases that exist, for example, in France, Germany and the UK. ${ }^{1}$ Other social security systems only provide a very basic compensation (compensating only a part of the employee's lost income and medical expenses), but the employee who wishes to obtain full compensation for his damages will, in these systems, have to rely on the tort liability of the employer. This is also the case if the victim seeks compensation for pain and suffering. These systems therefore allow for a combination of social security and tort liability. In other systems, tort liability of the employer's tort liability for the consequences of occupational diseases is excluded or limited to cases of intent or gross negligence.

All of these different compensation models not only have different costs and benefits as far as their ability to compensate the injured employee is concerned, but also have different consequences for the prevention of occupational diseases. Whereas most systems largely rely on government regulation to prevent occupational diseases, there is an increasing awareness that the compensation model chosen may provide additional incentives for prevention for the employer and the employee. This paper attempts to identify various compensation models for occupational diseases, illustrates their comparative benefits and, more specifically, analyses their ability to contribute to the prevention of occupational diseases. ${ }^{2}$

A lot of attention to the various models of compensation has already been given in the literature. ${ }^{3}$ However, this paper will address compensation models from a different angle than the traditional literature on social security law. The method to be followed in this paper is the economic analysis of law, also referred to as law and economics. The economic analysis of law has paid a great deal of attention to the ability of various legal instruments to contribute to the prevention of harm. The law and economics methodology has often been used to analyse inter alia, the preventive effect of liability

$1 \quad$ For a recent account see for example the contributions in Van Langendonck, J. (ed.), The Right to Social Security, Antwerp, Intersentia, 2007 and more particularly the contributions of Epsen (on Germany) and Parry (on the United Kingdom).

2 In this respect this paper builds on earlier research, more particularly the work of Dewees et al. (1996) and Danzon (1987), in which the various options to compensate for occupational diseases have also been reviewed. This paper attempts to add to that earlier research by taking some recent evolutions and literature into account and by providing a few examples from a variety of European countries.

3 See Adnett and Dawson, 1998, pp. 241-256; Chelius, 1973-74, pp. 700-729 and Oi, 1973-74, pp. $669-699$. 
rules, but less so to analyse the effects of instruments that traditionally belong to the area of social security, like the compensation for occupational diseases. ${ }^{4}$ Most of this economic literature is of a theoretical nature. Although this undoubtedly has its limits, obtaining insight into the way in which these various compensation mechanisms function from a theoretical perspective can be very useful. However, there is some empirical literature that addresses the effects of safety regulations and various liability rules on the prevention of occupational diseases that will be presented as well.

The domain of compensation for occupational diseases is so wide that it is impossible to provide a complete overview of the literature in one paper. Hence, only the most important findings are presented and summarised in a problem-oriented manner. For further information and details, the reader is referred to the bibliography. In addition to this, the different models are exemplified in many legal systems, which are not discussed in any detail. Some examples are, however, provided from experience in Belgium and the Netherlands. The latter country is particularly interesting, since a great deal of debate is currently taking place about the way in which effective compensation for damages caused by occupational diseases should take place. When referring to damages, it is clear that occupational diseases cause personal injury and consequential economic losses. There may occasionally be property damage as well. Although the central focus of this paper is on compensation for occupational diseases. it is clear that some of the findings also apply to industrial accidents. The vast literature on instruments to prevent occupational diseases, particularly the literature on regulation, is not addressed but the question of the extent to which compensation mechanisms can have a supplementary effect as far as prevention is considered.

This paper attempts to address the theoretical possibilities for compensating damages caused by occupational diseases from a law and economics perspective. By reviewing the law and economics literature, which addresses comparative benefits of different systems, the paper seeks to demonstrate the usefulness of the law and economics approach in comparing different institutional arrangements for dealing with compensation for the damage caused by occupational diseases. It is in this sense that the paper is theoretical. However, to an important extent the various compensation models (and more particularly the combinations of these models) do indeed (to different extents) exist in different legal systems. To demonstrate the importance of the workings of various systems in practice, some examples are provided, mostly from the Netherlands and Belgium. These countries are particularly interesting since their approaches to the compensation of damage caused by occupational diseases differ in important respects.

4 See, however, the important contribution by Danzon, 1987, pp. 263-282. 
Like most of the law and economics literature, the paper makes a basic distinction between tort law and social security as a compensation mechanism. ${ }^{5}$ Thus, the differences between the tort law system, including its coverage through liability insurance, and basic social security systems will be discussed from an economic perspective. In practice, for occupational accidents and diseases, there are social insurance schemes that provide compensation above the basic level provided by other social security schemes. These social insurance schemes as they exist, for example, in Belgium, are discussed from an economic perspective under the heading of first party and direct insurance schemes.

The paper is structured as follows: after this introduction (1), the various goals of a compensation mechanism are sketched (2). Attention is then paid to the possible contribution of liability rules in this respect (3) and to liability insurance (4). Next, some differences between basic social security systems and liability are highlighted (5) and attention is given to the various forms a social security compensation mechanism could adopt. Before doing so, the issue of whether compensation should be provided through the market or by government is discussed (6). Next, attention is given to the possible role of compensation funds (7) and first party or direct insurance schemes (8). The latter are particularly important since many of the social insurance schemes for occupational accidents and diseases that exist in many countries, like Belgium, take the form of first party or direct insurance schemes. In addition, some of the empirical literature with respect to compensation for occupational diseases is summarised. Finally, a few concluding observations are formulated (9).

\section{PREVENTION AND/OR COMPENSATION}

\subsection{TORT LAW: PREVENTION}

What should be the goal of a compensation system? It is useful to address this question by pointing to the differences between tort law and social security. On the one hand, this illustrates the importance of identifying the goals of a compensation mechanism and, on the other hand, it provides an introduction into the economic approach of the topic. Economists assume that tort law is an instrument to deter activities that should be avoided on efficiency grounds through liability rules. The idea is that the expectation to be held liable, expost will induce potential parties in an accident setting, ex ante to take greater care. Therefore, for the economist, the most important goal of tort law is the prevention of accidents. ${ }^{6}$

\footnotetext{
$5 \quad$ See in that respect also Skogh $(1982,1989)$.

6 For some of the basic insights in the economic analysis of tort law, see Calabresi, 1970 and Shavell, 1987.
} 
Some people see a difference between the legal approach and the economic approach. While economists emphasise the importance of tort rules as having an ex ante effect on prevention, traditional tort lawyers stress the ex post compensatory function of a tort rule. One could exaggerate the difference between the traditional economic and the classic legal approach by saying that the economist is interested in the prevention of accidents, while the lawyer is interested in victim compensation. However, reality is more balanced. Some economists (or lawyers writing in the economic tradition of law) point out the loss spreading function of tort rules (and therefore implicitly at victim compensation); $;^{7}$ while some lawyers (although there are also differences in legal systems) stress the preventive function of tort rules. This is, for example, the case in Austrian and in German tort law. ${ }^{8}$ Moreover, in a brilliant study, Schwartz has demonstrated that tort rules can be seen to serve both the goals of prevention and compensation, which is often referred to as 'corrective justice'.

Notwithstanding these nuances, which somehow reconcile legal and economic thought concerning the goals of tort law, it should be kept in mind that, from an economic point of view, liability rules function primarily as an incentive system. The idea is that the foresight of being held liable after an accident will encourage a change of behaviour towards taking precautionary measures before the accident happens. In this basic framework, the fact that a victim may be compensated after an accident is not considered a goal of tort law, but a means for providing incentives for preventive behaviour to a potential injurer. It is important to make it clear that, although this paper outlines the economic approach to liability law; it does not, at the normative level, assume that the economic goal of social welfare maximisation through deterrence is always the preferred goal at a policy level. It may be that, as far as compensation for work-related incidents is concerned, policy makers have other goals in addition to economic goals that they wish to serve. For example, a fair distribution of accident costs and the wish to provide employees a reasonable amount of compensation when they suffer harm may not be goals that fit into an economic analysis, but they nevertheless constitute an important motivation for many of the rules underlying social security or social insurance schemes that deal with occupational diseases. ${ }^{10}$

From an economic perspective, the goal of the legal system is to provide incentives to the parties involved to take optimal precaution for the prevention of harm. The literature has paid a lot of attention to the way in which a negligence regime or a strict liability regime can provide injurers with incentives to take optimal preventive measures to reduce a risk. The outcome is that, in so-called unilateral cases, where

This is, e.g., the case in Calabresi's notion of secondary costs, which aims at loss spreading.

8 The various goals of tort law have, from a legal perspective, also been elaborated in the famous handbook on Austrian tort law of Koziol, 1997a, pp. 8-13.

9 See Schwartz, 1997, pp. 1804-1834.

10 For the various goals of tort law and compensation systems see Ogus, 2007. 
only one party influences the accident risk, strict liability can achieve the same level of deterrence as negligence. In the case of a bilateral accident, where the victim, i.e. the employee, influences the accident risk, a defence has to be added to strict liability to provide victims with incentives for optimal precautions to prevent harm. ${ }^{11}$ Thus both strict liability (with a defence taking into account the victims behaviour) and negligence can achieve the same level of deterrence. An important difference between negligence and strict liability is that if the negligence rule works properly, it will provide an injurer with incentives to follow the appropriate care required by case law. The effect will be that if an accident happens although preventive measures was adopted and due care was taken, the injurer will not be bound to compensate the victim. Under a correctly working negligence rule, the victim is hence not compensated. The result is, in principle, the opposite under strict liability: if one defines strict liability simply as a rule whereby the injurer is always held to compensate the victim, the victim will, under strict liability (if one disregards the insolvency problem), always be compensated. ${ }^{12}$

\subsection{SOCIAL SECURITY: COMPENSATION}

The function of tort law from an economic perspective provides incentives to the parties involved, allowing them to take the optimal precautions for the prevention of harm. Compensation is only an instrument that forces a potential injurer to take preventive measures. The opposite is obviously the case if one regards a social security system from an economic perspective. The major goal of social security is to provide, depending upon the services provided, compensation, e.g., for lost income or health care), in principle, irrespective of the source of the illness. ${ }^{13}$

If one wants to identify a dividing line between tort law and social security law as far as personal injuries are concerned, one could say, from an economic perspective, the general function of tort law is to provide optimal precautions for the prevention of accidents. On the other hand, the general goal of social security law is to provide compensation for the damages caused as a result of personal injuries. It follows that a major difference that follows from this dividing line is that tort law is triggered as a result of an accident, in which a third party is held liable for having caused the personal injury. This is not at all necessary under social security. Social security is a system in which compensation is, if the legal conditions are met, provided directly to the protected victim, irrespective of whether his personal injury was caused by a liable third party. It may well be that social security intervenes in cases where it

$11 \quad$ See Shavell, 1980.

12 See for details on these differences Shavell, 1980, 1-25.

13 The way the particular system is organised obviously differs a lot and is dependent upon the particular legal system. See for principles of social security and for an introduction to the social security systems in Europe Pieters, 1993a and Pieters, 1993b. 
was entirely the victim's fault that personal injury was caused. ${ }^{14}$ However, in social security prevention of harm is increasingly stressed as being important. ${ }^{15}$ Although, the payments made under the social security schemes cannot be considered to have a predominant preventive goal. Traditional social security still focuses on compensation of losses. ${ }^{16}$

\subsection{COMBINATION OF INSTRUMENTS}

Although the goals can thus be clearly separated, at least from a theoretical perspective, in practice one often finds a combination of various instruments for securing deterrence and compensation for work related injuries. For instance, even in a system which relies primarily on tort law, the tort system, which from an economic perspective focuses on deterrence, may be complemented by systems of insurance to meet the goal of compensation. Thus, a potential tortfeasor could take out liability insurance coverage, which might (if the injurer is found liable) serve the interests of the victims as well, since it provides a guarantee against the insolvency of the potential injurer. Moreover, under a pure tort system, victims who fear that they would receive no compensation could choose to take out first-party insurance coverage for personal injury losses. This often happens in practice: many potential victims take out accident insurance to provide additional coverage in case they are personally injured. Hence, the deterrence-oriented tort system can be combined with (liability or first party) insurance schemes to serve the goal of compensation. ${ }^{17}$

The same applies for a system whereby automatic compensation (irrespective of the behaviour of the beneficiary) that would take place under social security. If such a perfectly working social security compensation mechanism existed, in which all potential victims were guaranteed compensation for their personal injuries, some system other than tort would be needed to guarantee that all those who may have an influence on the accident risk behave properly. The systems that are then advocated in combination with social security are systems of safety regulation. Thus, the model assumes that victims are compensated via social security or social insurance schemes, in which this is combined with ex ante government regulation which is enforced

\footnotetext{
14 The principle that social security provides compensation irrespective of the behaviour of the beneficiary may well be different in some legal systems; one can imagine cases where compensation under social security is reduced or even denied if, e.g., the personal injury was caused intentionally.

15 See Klosse, 2000, p. 12. Prevention in social security is equally stressed by Van Kessel, 2000, p. 257-260.

16 Klosse (supra note 16), pp. 8-9.

17 See Hartlief, 1997, p. 28.
} 
via administrative or criminal law. Regulation, not tort law, then serves the goal of deterrence. ${ }^{18}$

This is a model which has been advocated by many economists: they have often argued that if society wishes to achieve the goals of deterring accidents and compensating victims for personal injury, it could choose between, on the one hand, a tort system (for deterrence) plus insurance systems (for compensation) or on the other hand a system of regulation (for deterrence) plus social security (for compensation). This combination of private and public regulation of safety has been advocated by Skogh. ${ }^{19}$ In practice, of course, a combination of all of these instruments of deterrence and compensation exists, although the focus on each of the particular instruments may change over time.

In conclusion, depending upon the principal system that is chosen, a variety of different instruments (and combinations) can be found to achieve the goals of deterrence and compensation. The paper can now focus more specifically on the instruments that could be used for the compensation of damage caused by occupational diseases and look at these alternatives from a different perspective. First, it addresses the question of whether a particular system (at least from a theoretical perspective) provides any incentives for prevention. Second, it raises the question of the ability of the particular system to provide compensation and third, it briefly asks how the system is financed. In this connection, the question of whether the structure of financing influences prevention and compensation plays a role again.

\section{LIABILITY}

\subsection{PREVENTION?}

The starting point from the economic perspective is that tort law is primarily an instrument that can provide incentives to potential employers to take efficient measures to prevent the exposure of employees to occupational diseases. The basic assumption of the economic approach is that employers, based on the foresight of being held liable, ex post will adopt efficient preventive mechanisms against occupational diseases in order to avoid being held liable after the occupational disease has caused damage. Nevertheless, it has often been stressed in the literature that the role of tort law, as far as the prevention of occupational diseases is concerned, can at most be a complementary one. Indeed, the reasons why tort law does not provide optimal incentives for prevention are well known: ${ }^{20}$ First, information on optimal preventive

\footnotetext{
18 For criteria on safety regulation see Shavell, 1984a, pp. 57-374 and Shavell, 1984b, pp. 271-280.

19 See Skogh, 1982, pp. 67-80 and Skogh, 1989, pp. 87-101.

20 This is a classic application of the economic criteria for regulation as developed inter alia by Shavell. See Shavell, 1984a, pp. 357-374 and Shavell, 1984b, pp. 271-280.
} 
technologies to avoid occupational diseases may in some cases be better known to the government than to individual employers. Second, tort law may not lead to optimal deterrence if the potential magnitude of the harm is larger than the individual wealth of the injurer. Given limited liability of some (corporate) employers and the potential large magnitude of losses caused by occupational diseases, this under deterrence through insolvency may be a serious problem. Third, there are many reasons why tort law may fail to have a deterrent effect, for instance because there can be a long lapse between the moment of exposure to a certain substance (e.g. an asbestos crystal) and the moment that the harm occurs (the well known latency problem). In addition, in the case of occupational diseases, a causal link with employment (let alone with a tort) may not always be easily established. ${ }^{21}$

For these reasons, it has been held in the literature on the so-called criteria for regulation that occupational diseases should primarily be prevented through the introduction of safety regulation. ${ }^{22}$ However, safety regulation is not perfect either. First, it can quickly become outdated and is not dynamic enough and is often rather static. Second, the norm imposed through regulation can be inefficiently low as a result of pressure from (industrial) interest groups. Third, the efficiency of regulation is always dependent on the effectiveness of enforcement, which may be weak. Fourth, regulation may never cover all possible diseases ex ante or all possible preventive techniques. That is why some people argue that exposing employers to liability can have a useful effect in supplementing some of the shortcomings of regulation. Tort law in that respect still has a preventive role, albeit a supplementary one, complementing regulation. ${ }^{23}$ The importance of tort law in preventing occupational diseases thus depends on the strength of regulation. The prevention of occupational diseases should depend primarily on regulatory measures, focusing on safety at work. If these measures prevent occupational diseases theoretically there would be no need for the complimentary preventive role of tort law. Only if the regulatory framework for preventing occupational diseases is not perfect can either tort law be used to provide supplementary incentives to employers. The foresight that they can be held liable to compensate employees suffering from occupational diseases even if the regulatory norms are complied with could then provide additional incentives. However, this supplementary preventive effect should not be exaggerated, since the weaknesses of tort law in this domain still remain a problem. In this respect, the fact that the disease may only appear many years after the exposure (and probably after the employment)

\footnotetext{
21 See on these problems also Danzon, 1987, pp. 270-272.

22 See generally Faure and Hartlief, 2003a, pp. 222-265.

23 See in that respect inter alia Rose-Ackerman, 1991, pp. 54-58.
} 
may seriously dilute the incentives of the employer to take ex ante efficient measures to prevent occupational diseases. ${ }^{24}$

\subsection{COMPENSATION?}

As far as the compensation is concerned, the role of tort law is often limited because of the high threshold that a victim often has to meet in order to hold an employer liable. Indeed, the basis of tort law (and in this respect it is clearly different than social security), is that the occurrence of damage as such is not enough. As the Dutch Supreme Court stated:

'The mere fact that a certain act took place which resulted in damage for another party does not necessarily imply that a claim on compensation exists on the basis of tort. ${ }^{25}$

Some other element needs to be added in order to grant the victim a right to compensation for their damages. Traditionally this was 'fault', although there is a clear tendency in many legal systems towards strict liability. ${ }^{26}$ In the literature, it is claimed that usually claimed that some shortcoming on the side of the injurer is required as basis for a liability in tort. ${ }^{27}$ The idea of a necessary shortcoming may be implicit in regimes of strict liability, but may nevertheless be present there as well. Hence, the ability of tort law to play a substantial role in the compensation of damages caused by occupational diseases may be limited since the employee must meet a relatively high threshold. Since occupational diseases may occur many years after exposure, the employee may need to demonstrate in their proof that, years ago, there was some shortcoming on the part of the employer, which has a causal relationship with the damage currently suffered.

A basic rule in tort law is that, if the victim can prove that their loss was caused by a wrongful (in the sense that it results from a shortcoming) act of the injurer he or she can, in principle, claim full compensation. This full compensation will only be reduced if the victim contributed to the loss. The essential ideas of liability law are therefore that the victim has a claim to full compensation for his or her loss if a causal relationship can be proven with a wrongful act. ${ }^{28}$

$24 \quad$ Also a recent study by the Munich Reinsurance Group concluded that it is difficult to provide appropriate incentives for preventing occupational diseases through tort law given the problem of latency. See Center of Competence for Workers, 2005.

25 Supreme Court 27 May 1994 (1994), Nederlandse Jurisprudentie, 590.

26 The tendency from fault to strict liability has also been addressed on economic grounds in Faure, 2002c, pp. 361-394.

27 For further details see Klosse and Vonk, 2000, p. 200.

28 Hartlief (supra note 17), pp. 26-28. 
Given these rather severe conditions, one can understand the rather limited scope of tort law for the compensation of accident victims. It is striking that, in this traditional (Dutch, but to some extent European) system, tort law was considered a luxury and of rather limited importance for the compensation of victims. Indeed, only a limited amount of the damage that occurs in society is covered by tort law. ${ }^{29}$ The largest part of the damages was covered either by social security or by private, first party insurance. Tort law can be considered as a 'luxury' in the sense that it provides a guarantee of, in principle, full compensation for the damages suffered and even compensation for non-pecuniary loss. It is something that, according to the literature, that the social security system cannot afford. ${ }^{30}$

It has been held that this 'luxury' of tort law can only be provided in exceptional circumstances and when specific conditions are met. Hence, tort law cannot guarantee full compensation to every victim of personal injury and certainly not to every victim of an occupational disease. In most systems, whether or not the victim can obtain this full compensation depends on the behaviour of the injurer. This corresponds with the economic insights sketched out above, namely that, in systems where tort law does not have to provide this social security function, it functions more to influence the behaviour of the injurer than to provide compensation.

\subsection{LIMITED IMPORTANCE}

This limited scope and importance of liability law for the compensation of victims of occupational diseases can also be illustrated with examples from some systems where there is still reliance on liability of the employer for occupational diseases, like those in the Netherlands and the UK. In the Netherlands, in the case of an occupational disease, social security provides limited compensation for lost income and takes care of expenses incurred by the health care system. This corresponds with the traditional view that social security should take care of the 'Existenzsicherung. ${ }^{31}$ In addition, tort law plays a role in the case of occupational diseases, albeit a modest one. Victims (i.e. employees suffering from an occupational disease) can only use tort law to receive compensation for that part of their income that was not covered by social security and to get compensation for non-pecuniary losses, which are not covered by social security. Prevention of occupational diseases is to a large extent guaranteed through health and safety regulation, which impose specific safety duties on employers.

This results in a system in which victims of an occupational disease receive compensation, primarily via the social security system, to provide some

\footnotetext{
29 This has also been proven empirically (by calculating the specific contribution of tort law compared to social security) by Bloembergen, 1980, pp. 16-17.

30 Hartlief (supra note 17), pp. 29-30.

31 See Koziol, 1997b, pp. 21-35.
} 
'Existenzsicherung'. Tort law can be used - if the specific conditions are met - for that part of the damage that was not covered by social security. Obviously, some interrelationship between those systems exists in the sense that - again, under specific conditions - the social security system might use tort law in an attempt to recover benefits paid to the victim. This is precisely the issue of recourse.

Given the traditional reliance on the social security system and the limited role of liability in the compensation of damages caused by occupational diseases one can understand that once the scope of the social security regime changes, it may have an impact on the role of liability rules. In the 1990s, substantial reforms of the social security system took place in the Netherlands. Some have held that, as a result of se reforms, there is an increasing need for victims to use the liability system to obtain compensation for losses that were traditionally covered by social security. A reduction of compensation under social security unavoidably leads to increasing pressure on employers' liability for occupational diseases. This may in turn lead to increased pressure on the liability insurance of employers. ${ }^{32}$

\section{LIABILITY INSURANCE}

In systems where employers are still exposed to liability for occupational diseases (like those in the Netherlands and in the UK), liability insurance may play an important role. On the one hand, it provides protection to employers against the exposure of liability and, on the other, it provides a guarantee to victims against the insolvency of the employer. How does such a liability insurance system work? Private insurance starts from the simple assumption that a demand for insurance arises from risk-averse individuals. These risk-averse individuals demand insurance cover, which is provided by insurers on competitive insurance markets. They aggregate similar but non-related risks into risk pools and are able to accept these risks because they can be spread over a large number of cases. To control moral hazard and adverse selection, the insurer distinguishes risks according to the individual risk posed by the particular insured party. Hence, a system of risk differentiation is applied whereby narrow risk pools are construed in such a way that the premium charged corresponds with the risk posed by the average insured person in that particular pool. An important feature of private insurance is, hence, that the price charged, i.e. the premium, corresponds with the risk.

The insurer often charges a higher premium than the fair price. This depends on his market position and on administrative costs. Depending on the degree of risk aversion of the insured party and the premium charged, the individual demands insurance coverage for specific risks to which they are averse.

32

See section 5.4., infra. 
Additionally, a major advantage of insurance that is stressed by the law and economics literature is that monitoring of the insured by the insurance company can cure the under-deterrence that may arise in the case where the tortfeasor's wealth is limited. Indeed, this so-called 'judgment-proof problem' has been extensively dealt with in the economics literature. ${ }^{33}$ If the expected damage in the UK greatly exceeds the employer's assets, the employer will only have an incentive to purchase liability insurance up to the amount of his limited assets. The 'judgment proof problem' can therefore lead to under-insurance and thus to under-deterrence. This is why many economists have favoured compulsory insurance as a solution to the insolvency problem. ${ }^{34}$ This is also an important argument in the context of employer's liability. The insurer will obviously have incentives to control the behaviour of the insured employer via the traditional instruments for the control of moral hazard, to be discussed below. Thus one can understand that in many systems liability insurance for employers covering occupational diseases or industrial accidents has been made mandatory.

\subsection{PREVENTION}

The question arises with the influence of liability insurance on prevention. Insurance systems are exposed to the well-known problem of moral hazard. The traditional answer is that there are basically two possible remedies for moral hazard: either the behaviour of the insured party is controlled by a corresponding adaptation of the premium or by partially exposing the insured party to risk, for example, through a deductible or through an upper limit on cover. ${ }^{35}$ Considering the first potential remedy, advanced in traditional insurance economics, one might argue that there should be some link between the risk, which an insured party poses, and the premium paid. In theory, this would mean that the premium should be higher - when an employer constitutes a higher risk of an occupational disease. In insurance economics theory, such an employer would then be classified as belonging to a high-risk group. Through such an individualisation of the risk, the insured party would then behave as if they were not insured at all and moral hazard would be avoided. The second wellknown possibility to control moral hazard is to partially expose the insured to risk, for example by introducing a deductible. All of these techniques can to some extent be applied by liability insurers in controlling the risk of occupational diseases. The lesson from economic theory is clear: if insurers wish to contribute to the prevention of occupational diseases (and in a competitive market that should precisely be their goal), they should align risks as much as possible to the individual situation of the

\footnotetext{
33 More particularly by Shavell, 1986.

34 See for example Jost, 1996 and Skogh, 2000 as well as Polborn, 1998.

35 Shavell, 1979, pp. 541-562.
} 
employer. Through risk differentiation, optimal incentives to the employer towards prevention of occupational diseases can be provided. Thus, at least in theory, liability insurance could constitute an important instrument in the prevention of occupational diseases. The question arises whether that is actually done in practice, which we will address below.

\subsection{COMPENSATION}

As far as compensation is concerned, a few comments should suffice: liability insurance cannot provide an absolute guarantee of compensation to the victim since insurance will only intervene if the employer is held to be liable. As mentioned above, the victim will have to meet the high thresholds of tort law before employers' liability for occupational diseases can be accepted (in systems where this is allowed at all). Moreover, in many countries, liability insurance for employers is not compulsory and there is no guarantee of compensation for the victim. A guarantee of compensation will only exist if additionally the victim has a direct right of action against the insurer of the liable employer. This is the case in the Belgian system of employers' liability for industrial accidents, where victims are granted a statutory right of action against the employer. ${ }^{36}$

\subsection{FINANCING}

As far as financing is concerned, financing is to be understood within a classic model of private insurance. Risk-averse employers will purchase (by choice or compulsorily) insurance from a competitive insurance market and pay a corresponding premium, related to their demand for insurance and to the individual risk they pose. Essential to private insurance is the fact that the premiums charged must correspond to the risk - not only to control moral hazard, but also to guarantee that funds will be available when the insured risk manifests itself. The premiums paid will in principle be reserved to account for any future risks that may occur. Insurers are under a contractual obligation to fulfil their contractual duties vis-à-vis insured parties. ${ }^{37}$ Hence, they will have to bear the employers' liability and consider this a 'hard to insure' risk. The reasons are many and have been well documented. ${ }^{38}$

36 However, we will argue below that therefore the system in fact is no longer liability insurance, but rather a system of direct insurance whereby the employer provides direct insurance to the benefit of a third party (in this case the victim of an industrial accident). See section 8 infra. on the liability insurance contract concluded by his employer. In some legal systems, legislation grants employees a direct right of action against the insurer of the employer. 
Several tendencies have led to an increased pressure on the insurance cover for employers' liability. One trend concerns the fact that, in some countries (like the Netherlands, but also in other countries), the government has increasingly withdrawn from the social security system. These cut-backs in social security systems, as a result of a general tendency towards deregulation in Western Europe in the 1990's, are clear. Some politicians have argued that victims of occupational diseases should make more use of the tort system because they regard this as a means of reducing the pressures on the social security system. As we have argued above, in those countries where the government has increasingly withdrawn from the compensation of personal injury via social security, victims have increasingly been forced to make use of tort law (and insurance) to meet this same goal.

At the same time, one can also see changes in the scope of employers' liability for occupational diseases. For instance, the Dutch Supreme Court decided, in a well-known asbestos case (Cijsouw v. De Schelde) to reverse the burden of proof in the case of causal uncertainty concerning the precise time when an employee had inhaled a fatal asbestos crystal, resulting in asbestosis. The Supreme Court shifted the uncertainty concerning causation to the enterprise by holding that it could be assumed that the employee had been in contact with the fatal asbestos fibre during the second period of his employment with the defendant. ${ }^{39}$ This presumption could have been rebutted if the defendant had been able to prove that Cijsouw was not in contact with the fatal fibre during the second period in which he was employed by the defendant. ${ }^{40}$ Obviously, this would have been practically impossible for the employer.

In many countries, the contributory negligence defence in the case of employer's liability has been severely reduced as a result of developments in case law. This can also be seen in the case law of the Dutch Supreme Court. It has, inter alia, been decided that there can only be a reduction of the employer's liability in cases of gross negligence on the part of the employee. ${ }^{41}$ As a result, liability, the burden of proof, causation as well as the interpretation of contributory negligence, all tend towards increased victim protection and in favour of increased employer's liability. Employees are not only protected against the dangers at work, but also against themselves. Some have claimed that such a tendency is contrary to the fundamental principle of liability law. ${ }^{42}$

Some insurers hold that they lack sufficient information to cover occupational health risks, particularly those caused by occupational diseases. The argument here is that there is both factual and legal uncertainty with respect to these risks. The problem is that, for liability insurance to work, an insurer needs information concerning the

Spier, 1996, pp. 124-125.

Dutch Supreme Court 25 juni 1993 (1993), Nederlandse Jurisprudentie, p. 686.

Hoge Raad, 9 January 1987 (1987), Nederlandse Jurisprudentie, p. 948.

42 So Hartlief (supra note 17), pp. 43-44. 
probability that a disease will occur and the possible magnitude of the damage. Insurers usually use statistics to obtain this information. However, some occupational hazards may be so new that this information will simply not be readily available (or only available at high cost). Of course, the literature indicates that there is a possible way to deal with the problem of so-called 'insurer ambiguity'. In cases of uncertainty concerning either the probability of the event or the magnitude of the damage, an insurer can charge a so-called risk premium to account for this unpredictability of the occupational health risk. ${ }^{43}$ The extent of the risk premium then reflects the uncertainty concerning the risk. However, a problem can still remain if the insured does not recognise the possibility of new occupational hazards and may thus not be willing to pay the corresponding risk premium.

A related problem is that insurers need to deal with the previously mentioned traditional insurance problems of moral hazard and adverse selection. As indicated, the traditional remedy is risk differentiation. ${ }^{44}$ This, however, requires that the insurer obtains adequate information on the risk that the particular employer would pose as far as occupational hazards are concerned and that they are subsequently held liable through case law. In addition, insurers also need information on the appropriate preventive measures for reducing the likelihood of occupational diseases, so that they can require these from insured employers through the premium conditions. In liability insurance, the problem also arises that the insurer is not only required to control the particular behaviour of their insured employer (to remedy moral hazard), but also to take into account the likelihood that this insured employer will be held liable in a particular liability case.

A final issue, which creates problems for the insurability of occupational diseases, relates to the fact that a long time often elapses between the moment that the potentially wrongful exposure takes place and the moment that the damage occurs. This is the well-known problem of latency, sometimes referred to as the problem of damage with a 'long-tail' character. Increasingly insurers try to tackle this problem, inter alia through the introduction of different policy conditions. However, this can never provide complete protection for the insurer.

All of these insurability problems are of a general nature. Indeed, insurers have argued that the increasing use of tort law for compensating primary needs may lead to unpredictable claims and hence to uninsurability. ${ }^{45}$ Insurers have already defended themselves against this 'claims culture' for occupational diseases by changing the system of coverage, policy conditions, etc. As a result of these reactions by insurers,

\footnotetext{
43 See generally Kunreuther, Hogarth and Meszaros, 1993, pp. 71-87.

44 See Shavell, 1979, pp. 541-562 and Priest, 1987, pp. 1521-1590.

45 With respect to insurance against environmental harm, see Abraham, 1982, pp. 123-131, Abraham, 1988, pp. 949-951 and Katzman, 1988, pp. 75-100.
} 
some victims may no longer receive compensation via tort law. ${ }^{46}$ If this is combined with reduced social security, some victims will not be compensated by either system.

One partial remedy that insurers have followed is changing the claims system from so-called loss occurrence to the claims made coverage system. ${ }^{47}$ However, this and other changes in liability coverage have the same aim in that they wish to limit the exposure to liability of insurers while, at the same time, limiting the availability of insurance for employers and thus for victims of occupational diseases. It has been suggested that the tendencies described above have led to increased pressures on liability insurance and that they have endangered the insurability of the liability risk. ${ }^{48}$ This explains why discussion has taken place, inter alia in the Netherlands, on reforms of compensation for damage caused by occupational diseases, away from employers liability and towards alternative systems based on first-party or direct insurance schemes. However, before addressing these alternatives, we first examine some basic features of 'classic' social security schemes and address their ability to provide prevention and compensation for occupational diseases.

\section{SOCIAL SECURITY}

\subsection{STARTING POINT: SOLIDARITY}

The starting point of social security is different from the starting point of private law systems like liability rules (and liability insurance) discussed above. ${ }^{49}$ Social security provides compensation, e.g. of lost income or health care expenses, irrespective of the cause of the illness or disability. In principle, the contributory negligence of the claimant does not exclude a claim for compensation in social security law. However, whereas in tort law the principle is full compensation, social security usually provides compensation that is limited in time and in amount: Existenzsicherung. Moreover, in social security, the financial situation of the victim might play a role in determining the amount of compensation. These redistributive elements are different from the basic approach of tort law in which a victim is, if the specific conditions of tort law are met, entitled to full compensation, irrespective of his personal wealth. ${ }^{50}$

A starting point for social security is the idea of solidarity between citizens. All citizens contribute, according to their income, to the social security system. Thus, the

46 There is, therefore, much criticism concerning the tendency towards claims-made coverage; see, e.g., Klosse and Vonk (supra note 27), pp. 216-217.

47 This means that the claim for damages must have been received by the insured or his insurer during the period of insurance cover.

48 See Faure and Hartlief, 2003c, pp. 81-120.

49 For the principles of social security law see generally Klosse and Vonk, 2000, pp. 196-198.

$50 \quad$ Hartlief (supra note 17), pp. 28-29. 
'working class' pay for those who, for a variety of reasons, cannot work (and hence do not contribute to social security) but who receive social security benefits. This, again, contrasts with tort law, which does not incorporate any principle of solidarity between injurers and victims. Only within liability insurance is it sometimes said that there is solidarity between all the insured. That, however, is a different type of solidarity than the one in social security. The solidarity referred to in insurance is only a system of risk spreading, whereby all insured (though premium payments) contribute to the loss when the risk occurs with one particular insured person. However, since premium payments are, in principle, risk based, bad risks should pay more than good risks and risk differentiation is the leading principle in insurance. ${ }^{51}$

\subsection{OCCUPATIONAL HAZARDS}

These features also allow us to provide some indication of the ability of social security systems to achieve prevention and compensation of occupational diseases..$^{52}$ As mentioned above, the threshold for calling on social security is, in principle, relatively low. Health care is provided, at least as far as basic needs are concerned, either totally free of charge or with a modest deductible for almost all citizens. Legal systems differ with respect to who can benefit from social security and to the amount of benefit they receive. In some countries, health care is simply provided free; in other countries the patient must pay, but can recover the expenses from his insurer or the (social) insurer pays the costs of the health care system directly. ${ }^{53}$ Within a social security system, equal access to the health care system is usually essential. In addition, the cost of social security is usually charged by withholding the premium from the wages of all employed workers. A part of the premium is therefore usually paid by employed persons themselves and, in addition, employers usually make substantial contributions. ${ }^{54}$ However, as noted above, most social security systems do not provide full compensation to the victim, but rather an Existenzsicherung. Social security therefore never provides the 'luxury' of full compensation, which is provided under tort law. Social security systems typically only cover health care and (depending upon the system) some compensation for lost income. However, under most systems, the basic social security neither covers the whole of ones income, nor provides compensation for pain and suffering. The latter is particularly significant

\footnotetext{
51 This is further developed in Faure, 1998, pp. 265-293.

52 Of course, one should be careful with generalizations since the particular features of the different systems can vary substantially. Here we therefore merely address some general features of social security systems from a theoretical perspective.

53 The way the system is organised may be dependent upon the particular legal system. For an introduction to the social security system in Europe see Pieters, $1993 \mathrm{~b}$.

54 From an economic perspective, one can of course argue that in fact the employer's contribution to the premium is also charged to the employee in the form of reduced salary.
} 
in the case of occupational diseases where (e.g. after exposure to asbestos) the victim eventually dies. In such cases, most of the damage often consists of non-pecuniary losses suffered by the victim and his family members. Social security systems often only provide standardised amounts, which rarely include an element to compensate these non-pecuniary losses.

\subsection{PREVENTION}

As far as prevention is concerned, we can see that the way premiums generally in social security systems charged in social security systems does not correspond with the traditional insurance economics answer to the moral hazard problem. First, the premium charged is usually income dependent and does not depend on the risk posed. Individual risk differentiation is, therefore, impossible or at least rarely applied. Second, the idea of a strong differentiation of risks seems to clash with the idea of solidarity between good risks and bad risks, which underlies many systems of social security. The need for risk differentiation may of course depend on the party who is actually financing the social security system. To the extent that employees (through reduced income) finance the system, risk differentiation would mean that high-risk individuals would have to pay higher premiums than low-risk individuals. From a policy perspective, it may not be desirable to charge some individuals higher premiums just because they contract an occupational disease. Of course, the mere fact that an employee suffers from an occupational disease does not make that individual a highrisk individual in the insurance economic sense. Moreover, the insurance economics idea of a risk-related premium seems to clash with the income redistributive goals of social security. ${ }^{55}$

In the particular case of occupational diseases, this traditional conflict between the insurance economics need for risk differentiation to control moral hazard and solidarity between good risks and bad risks in social security, does not seem to lead to insurmountable problems. Indeed, the problem in the case of occupational diseases does not seem to be moral hazard on the part of the victim, but rather on the part of the employer. Indeed, moral hazard on the part of the victim is, in practice, easily controllable either by imposing a deductible or by an upper limit on benefits. In practice, the compensation awarded in the case of occupational diseases never provides full compensation and is an appropriate instrument against the excessive demand for particular services. ${ }^{56}$ It seems more important in social security systems that risk dependant pricing takes place as far as the particular employer is concerned.

$55 \quad$ Van Mierlo (1991, p. 1164) has pointed out that the government confuses two policy goals: namely guaranteeing equal access to health care and income redistribution.

56 On this increasing debate on the promotion of preventative health care see the contributions in Van Wijngaarden, Van den Heuvel and Vrooman, 1992; and Whinston, 1983, pp. 49-71. 
In the case of occupational diseases, the employer's contribution in controlling the risk is far more important than the danger of contributory negligence on the part of the employee. The latter can easily be controlled since social security systems do not provide full coverage. Exposing the partially insured to risk has always been considered as one possibility for controlling moral hazard. In addition, it seems important that, as is now increasingly done in practice, social security systems differentiate as far as possible between employers in order to provide them with efficient incentives to prevent occupational diseases.

This account has shown that the principle of solidarity (which is fundamental of social security) may apply to the victims of occupational diseases. This means that they will be equally treated and receive benefits irrespective of their personal situations. ${ }^{57}$ However, solidarity on the part of the receivers is not in conflict with risk differentiation on the part of employers. From an economic perspective, it is important to find a financing structure (either through premium differentiation or through other mechanisms) that provides incentives to employers to take measures to prevent occupational diseases.

All of these observations apply to traditional social security instruments that provide compensation for basic needs (Existenzsicherung) and are primarily financed through income dependant premiums. However, as we already made clear in the introduction, in many legal systems occupational accidents and diseases are covered through special social insurance schemes. These provide often compensation above the basic needs level and in some cases involve risk dependant premiums. The premium in those particular cases is then dependant upon specific risks posed by the particular employer. For example, this is the case in Belgium for industrial accidents where commercial insurers charge risk related premiums. ${ }^{58}$ Hence, these systems will be further discussed in paragraph 8 which is related to first party and direct insurance schemes which are usually considered as 'social insurances'.

\subsection{COMPENSATION}

Fault traditionally does not play a role in social security systems: a victim can claim compensation under social security without having to prove the fault of a third party. That is different in tort law, where a wrongful act has to be proven. Moreover, in social security, the victim only needs to prove that a certain condition (e.g., illness or unemployment) meets the statutory requirements for compensation. It is not necessary to prove a causal link between this condition (which gave rise to the loss) and the act of

\footnotetext{
57 Although obviously the lost income will often be the largest part of the damage and thus the wealthier victims will of course in most cases receive more compensation than the poor.

58 See on the Belgian compensation for accidents at work inter alia Van Langendonck, 1988, pp. 73-88 and Rauws, 2001, pp. 109-129.
} 
a third party (which is typically a requirement of tort law). ${ }^{59} \mathrm{~A}$ typical feature of Dutch social security and more particularly of payments that are based on disability is the so-called 'risque social'. The basic idea in the Netherlands is that if someone has lost his capacity to work, social security (in that particular case the so-called WAO) will provide replacement income, irrespective of the cause of the disability. Tort law, on the other hand, provides - in principle - full compensation, both of pecuniary and of nonpecuniary loss (although the amount and scope will differ in different legal systems), whereas social security systems traditionally only cover pecuniary loss (and even then are usually limited in time and amount). Contributory negligence almost never plays a role in social security systems (except perhaps in extreme cases of intentional acts by the victim), whereas in most tort law systems contributory negligence of the victim will lead to a reduction of the claim on the part of the victim.

Overall, although there are of course many differences between the legal systems, victims of an occupational disease who are compensated through the social security system will typically face a low threshold for compensation, but will on the other hand usually not receive full compensation. ${ }^{60}$ Indeed, social security will provide standardised amounts to victims of occupational diseases. That is, as mentioned above, the typical feature of social security systems, which often applies to victims of occupational diseases as well.

Indeed, the essence of an 'Existenzsicherung' (in social security) is that it provides a minimum, but not the 'luxury' of full compensation. The economic reasons why the social security system cannot guarantee full compensation (including compensation for non-pecuniary losses) are manifold; the costs of full recovery would be high and would either lead to higher premiums or to increased pressure on public budgets. In addition, non-pecuniary loss would be different for every individual, whereas social security usually works with more or less fixed, at least standardised, levels of compensation.

It should be made clear that low amounts of compensation are usually paid under the traditional social security systems. The situation may be different, however, when the particular legal system does not merely have a basic social security system, but a special social insurance scheme for occupational accidents and diseases. Some of these systems (of which are discussed in more detail below) provide higher levels of compensation and in some cases even a lump sum compensation for non-pecuniary losses.

\footnotetext{
59 For an account of the historic evolution of social security in the Netherlands see Hoop, forthcoming.

60 See further Faure and Hartlief, 2003c, pp. 44-51.
} 


\subsection{FINANCING}

The financing of the social security systems is important both for prevention and for compensation. Social security systems, as they have been developed since Bismarck's initiative in the late 19 th century, ${ }^{61}$ assume that a minimum of social services, including health care, are delivered to those who could not afford to purchase these services themselves. However, in many cases the principle of solidarity between good risks and bad risks will lead to income-dependent premium setting. This inevitably leads to the question of whether such income-dependent premium setting can be reconciled with the insurance economics goal of avoiding moral hazard. This may in theory be problematic, given the different starting points of the two systems. However, as far as employers' liability for occupational diseases is concerned, there seems to be sufficient scope for risk related premium setting especially when such a differentiation (between employers) can be done at relatively low cost. Thus, the financing system can be such that there can still be solidarity on the side of the victims and a risk related financing (premium setting) to provide employers with incentives for prevention.

The financing system of (most) social security systems also has consequences for the issue of compensation. Unlike private insurers, the government providing social insurance is not under a contractual duty to compensate the insured fully. Since the income of the social health care system is not risk related, there is a chance that, at some moment, the amount allocated to the social health care system may not be sufficient to pay for it. In that case, the government may either lower the payments due (through regulatory intervention) or look for additional sources of funding (say, from general income tax revenues). This illustrates the basic difference between the finance of private and social insurance schemes. An important consequence is that a shift from social to private insurance not only has downsides for the insured because, unlike the government which can always reduce social insurance benefits because of budget constraints, an insurer is bound to his contractual duties. ${ }^{62}$ Some scholars indeed argue that a shift to a privatised system has advantages for the insured parties since it would reduce the level of political risk. ${ }^{63}$

\section{SOCIAL SECURITY VIA THE MARKET OR THE GOVERNMENT?}

So far, we have assumed a clear dividing line between private law and tort law systems supplemented with (liability) insurance on the one hand and social security

61 See Le Blanc, 1990, pp. 654-659 and Fuchs, 1976, pp. 347-359.

62 See Dijkshoorn, 1996, pp. 82-86.

63 Mitchell and Zeldes, 1996, p. 11, consider redistribution and national risk sharing as essential features of the social security system. 
systems on the other hand. It was implicitly assumed that social security systems are organized by governments or governmental agencies and that the funding is income related or generated via general tax systems. One can of course question whether that dividing line is always that clear. In some cases, there may be grey zones in which private insurers play a role in providing social security. This could be the case when mandatory insurance for industrial accidents is provided through private insurers (as in Belgium) although this is still considered a part of the social security system. In addition, one could ask why a regime that is considered part of social security should necessarily be provided through governmental institutions.

There are clear differences between social security, which, in most Western European systems, is provided through government intervention, and private insurance provided by insurance companies operating in a competitive market.

As far as the choice between government-provided or private market insurance is concerned, an economist would usually refer to the theory of bureaucracies to argue that government-owned operations that are not exposed to competitive pressures have little incentive for efficient production and are therefore likely to be more expensive than private insurance companies providing the same product. ${ }^{64}$ Generally, one could therefore argue that insurance cover should be provided by the private market, even if it were to be decided that these risks should be subject to compulsory insurance. ${ }^{65}$ There are indeed many examples of compulsory insurance where the cover is not provided through social insurance or government-owned institutions but through private insurance companies. This, however, assumes that private insurance markets are sufficiently competitive. In that case, insurance theory predicts that a diversified supply of different insurance policies will be provided at competitive premiums. Only if the private insurance market is incapable of covering certain risks or would provide inefficient results, because, for example, of a high degree of market concentration, is there an argument for government intervention. ${ }^{66}$ Another argument in favour of government intervention could be that certain risks are uninsurable in the private market, perhaps because of an incurable problem of adverse selection. If the government could gather information on the risk at a lower cost than insurance companies could, this would be an argument for government provided insurance. ${ }^{67}$

\footnotetext{
64 See generally Ferejohn and Shipan, 1990, pp. 1-20.

65 In a similar vein, the Netherlands Scientific Council for Government Policy argued in a 1994 report 'Belang en beleid' (Interest and Policy) that the public sector lacks the incentive which the private sector has to reduce the volume of health care costs (see Dijkshoorn, 1996, pp. 82-86).

66 On the negative consequences of restrictions on competition on the insurance market, see Faure and Van den Bergh, 1993, pp. 261-267 and Faure and Van den Bergh, 1995, pp. 65-85; and, with respect to health care insurance, Pauly, 1988, pp. 237-271.

67 See Johnson, 1977, pp. 23-25; Pauly, 1974, pp. 44-62 and Rothschild and Stiglitz, 1976, pp. 629649.
} 
This shows that, in arguing that private insurers are in principle better than bureaucratic institutions at providing cover at competitive premiums, there is a strong case for private insurance. These arguments do, of course, apply within the context of compensation for occupational diseases as well. As long as there is a competitive insurance market and sufficient cover can be provided, there is a strong case, involving the classic argument that competition will drive down prices and increase quality, in favour of using the private market.

However, we already indicated that, especially as far as employers' liability is concerned, many insurers have serious problems with the coverage of occupational diseases. Hence, some risks may be uninsurable on the private market. Thus, there may be a case for government intervention to provide coverage for those categories that cannot obtain insurance cover on the regular market. ${ }^{68}$ This is precisely the model that is followed in Belgium as far as industrial accidents are concerned: employers have to take out (mandatory) cover for industrial accidents for the benefit of employees. This cover can be obtained in the private market and is provided by commercial insurers. However, those employers who do not take out the mandatory coverage are automatically insured via the Government Fund for Industrial Accidents. ${ }^{69}$

One should, nevertheless, be careful about making generalised conclusions. For example, recent research comparing Spain and Argentina showed that in Spain, where private insurers play an increasingly important role, employers pay a fixed premium that is not risk related (and hence there is no relationship with preventive efforts) whereas in Argentina, the state plays a more important role in occupational health and provides incentives to employers to intervene in prevention. In Argentina, a reduction in the number and severity of accidents leads to a lower premium and thus provides appropriate incentives. ${ }^{70}$

So far, we have considered the choice between insurance via the private market or government provision, assuming that cover for occupational diseases can be provided via the private market, with risk-based premiums, taking into account the general principles of insurance, in particular risk differentiation. From this point of view, we have argued that government intervention is not necessary as long as insurance is provided in a competitive market and moral hazard as well as adverse selection is controlled. The problem is, once more, that social security policy apparently often aims at income redistribution as well. Therefore social security contributions are often not risk based but are instead income dependent. This inevitably clashes with the insurance principle that premiums should correspond with real risks. However,

\footnotetext{
68 This is of course a debate, which also takes place with respect to general health care insurance. See in this respect for example, on the Medicaid system in the US, Van de Griendt, 1995, pp. 9-12 and Frank, 1997, pp. 122-123.

69 Fonds voor Arbeidsongevallen.

$70 \quad$ See Suarez Serrano and Loredo Fernandez, 2001, pp. 41-57.
} 
this income redistributive goal can probably only be realised through government intervention.

The conflict between risk differentiation and income redistribution seems far more serious in the area of health care insurance than in the area of occupational diseases. In the latter area, there seem to be very few objections to the financing of compensation for occupational diseases via risk-based premiums paid by employers. Problems arise in this respect only when one addresses the general issue of the private contributions of individuals to health care insurance. In that case, social security systems usually also have a redistributive goal. It follows, that the question of whether government intervention is necessary can only be answered when the aim of social security policy has been clarified. This choice inevitably incorporates a normative element. If income redistribution is considered to be the aim of social security, it is obviously not possible to accomplish risk differentiation at the same time.

\section{COMPENSATION FUNDS}

\subsection{A SEARCH FOR ALTERNATIVES FOR EMPLOYER'S LIABILITY}

We have already mentioned that, in those legal systems (like in the Netherlands) where employers are still exposed to employers' liability for occupational diseases, the changing relationship between tort law and social security has led to an increasing pressure on liability law and liability insurance. Both insurers and victims have complained about this expanding liability, especially in the field of occupational health, but also in many other fields of tort law. A tendency towards expanding liability cannot only be noticed for occupational diseases, but can be seen in all those areas where personal injury occurs. ${ }^{71}$ One can obviously understand why enterprises and those they insure complain about the expanding scope of liability. However, the current Dutch system is unsatisfactory for victims as well. Victims complain that civil procedures take far too long; that too much money is spent on trial costs and that the outcome of a (employer's) liability trial is often uncertain. Moreover, even if, after a civil trial lasting years, the employer is finally held liable, there is still a risk of insolvency. ${ }^{72}$ For these reasons, many people have been argued for alternatives to the traditional tort system in order to compensate occupational diseases. ${ }^{73}$ A first option, which has been advanced on many occasions in the Netherlands, is the introduction

\footnotetext{
$71 \quad$ For a detailed overview of all the areas where an expanding tort liability could be noticed in the Netherlands see Bolt and Spier, 1996. For the insurance consequences see Spier and Haazen, 1996, pp. $45-50$.

72 See Faure and Hartlief, 1998a, p. 1139.

73 See for the discussion of these alternatives also Klosse and Vonk (supra note 27), pp. 214-217.
} 
of a compensation fund. ${ }^{74}$ Compensation funds are now often proposed in cases where victims have difficulties in obtaining compensation via the tort system.

\subsection{PREVENTION AND COMPENSATION}

From an economic perspective, it can be argued that, no matter how a compensation system is organised, the incentives for preventing occupational diseases should always remain untouched. This means that the principles of risk differentiation should be applied if a compensation fund is set up. ${ }^{75}$ In other words, bad risks should in principle contribute more to the compensation system than good risks. These principles are important because they provide optimal incentives for prevention but also include an element of fairness. In the case of standardised contributions, there would be cross-subsidisation from good risks to bad risks. ${ }^{76}$ Hence, it seems doubtful that a compensation fund can substantially contribute to the prevention of occupational diseases, unless risk-based contributions are claimed from employers. Also, as far as compensation is concerned, it is likely that a compensation fund will resemble a social security system in the sense that standardised payments will be made. These usually do not provide full compensation and do not include non-pecuniary losses.

The question of why, if in theory both a compensation fund and insurance are available, a compensation fund is to be preferred, can also be asked. One can assume that an insurer is better able to differentiate risks since insurers specialise in risk differentiation and risk spreading. ${ }^{77}$ However, as indicated above, although this may generally be the case, it is not necessarily so in the context of occupational diseases. If it can be argued that the manager of a fund is better able to differentiate risks of occupational diseases, than an insurer, there might be a case in favour of the fund. This, however, assumes that the fund is financed through risk dependant premiums. Comparing insurance with compensation funds, the costs of both instruments can be compared. Provided that an insurer specialises in acquiring information on the differentiation of risks, one can assume that the costs of a risk spreading might be lower with an insurance company than with a bureaucratic compensation fund. The key issue is that funds are often bureaucratic and thus have no incentives for cost reduction. Competition would drive insurers towards cost reduction. This, again, assumes that the insurance market is competitive and that insurers are indeed better able to differentiate risks at low costs. If these conditions are not met, the comparative advantage of insurance again disappears. One can envisage a fund where liability

See Hustinx and Stolker, 1997, p. 58 et seq.

See Danzon, 1987, p. 279.

Therefore, some have been critical of the use of compensation fund in the context of environmental harm. See for instance Faure and Hartlief, 1996a), pp. 235-270 and, more generally, Faure and Hartlief, 1998b, pp. 211-228.

77 See Danzon, 1987, p. 279. 
and insurance are simply not alternatives, for example, in the case of harm whose source lies in the distant past, like with asbestos. Since the fund already applies to injuries, incurred prevention is not an issue and the fund merely has a redistributive character. $^{78}$

\subsection{PRACTICE}

When considering practice, one has to make a distinction between various types of compensation funds. The compensation fund that is often referred to in this case is the general compensation fund, which constitutes a substitute for liability and insurance. That can work well if it takes over the functions of the insurance system, including risk differentiation. Another type of fund that has been advanced as a remedy for long lasting civil procedures, particularly in the case of asbestos victims, is the so-called advance payment fund. Such a fund would advance payments to victims to remedy the long duration of civil procedures, given the relatively short life expectation of most asbestos victims. ${ }^{79}$ In that case, the compensation fund could still use tort law to claim compensation from the liable employer. ${ }^{80}$

One has to be very careful when compensation funds are considered since, under the heading of 'compensation funds', many different compensation techniques exist. As far as the Netherlands is concerned, one can point at pleadings by the former Minister of Justice De Ruiter for the creation of an asbestos fund. ${ }^{81}$ These proposals of De Ruiter's proposals have finally led to the erection of an institute for asbestos victims, which helps and assists victims in their claims against employers. Although, the asbestos fund only has a limited scope today, it fits in with a general tendency in the Netherlands in favour of the replacement of tort law, especially in cases of mass torts, by compensation funds. There have, however, been serious criticisms of this proposal. It has been argued that, if compensation funds functioned according to the same principles of efficiency and justice as tort law, similar problems would arise. ${ }^{82}$ The advancement fund, as advanced in the Netherlands for asbestos victims, has a relatively limited scope. The traditional liability and insurance system remains untouched and the fund would only provide advancement to the victim.

A more general compensation fund for occupational diseases can, for example, be found in Belgium, which established an occupational diseases fund ${ }^{83}$ in $1967 .{ }^{84}$

\footnotetext{
78 Danzon, 1987, p. 278.

79 See on those proposals Woertmann, 1995, pp. 181-182 and Faure and Hartlief, 1996b, pp. 37-43.

80 See Faure and Hartlief, 1996b, pp. 37-43.

81 See Dommering-van Rongen, 1996, p. 96 et seq. and Frenk, 1997, pp. 295-298.

82 See Faure and Hartlief, 1996a, pp. 321-326.

83 Fonds voor beroepsziekten.

84 Note that Belgium also has a Fund for Industrial Accidents. However, as far as industrial accidents are concerned, in principle a compulsory employers' insurance exists for the benefit of the victims. The
} 
The fund provides standardised amounts of compensation for lost income that are dependant on the extent of disability of the victim (and of course, the income lost). However, this fund suffers from all of the shortcomings of fund solutions, mentioned above. As far as prevention is concerned, there is a no risk related financial contribution to this fund whatsoever. The contributions are hence not incentive driven. Moreover, the payments are standardised and therefore provide far from complete compensation for the victim. ${ }^{85}$ The question therefore arises whether there is no alternative mechanism that could provide better solutions, as far as prevention and compensation is concerned.

\section{FIRST-PARTY AND DIRECT INSURANCE SCHEMES}

\subsection{FIRST-PARTY, DIRECT AND THIRD-PARTY INSURANCE}

An alternative, which is already known in many legal systems and is often advocated today as a replacement for liability insurance is a first-party insurance. Liability insurance is a third-party insurance, in which the insurer covers the risk that the insured person (the employer in case of employers' liability) will have to compensate a third party (the employee). A first-party insurance is based on the principle that the insurer compensates the victim directly. This first-party insurance is now advanced by many as an attractive alternative to liability insurance, e.g. in the field of environmental liability, Dutch insurers have completely moved away from liability insurance and replaced liability policies by first-party coverage. ${ }^{86} \mathrm{~A}$ similar discussion is taking place over personal injury. ${ }^{87}$ Some people would like to change employers' liability to a system of compulsory first-party insurance for the benefit of employees. ${ }^{88}$ In the Netherlands, a proposal has been launched to move to a so-called extra guarantee arrangement for occupational diseases. ${ }^{89}$ This so-called EGB would function like direct insurance and would have to be taken out by the employer for the benefit of employees who are the victims of occupational diseases.

Fund for Industrial Accidents only acts as insurer of last resort for those employers who did not take out insurance coverage with a commercial insurer. For occupational diseases, a 'true' compensation fund has been set up. This once more shows the confusion created as far as compensation funds are concerned since the same wording is used for solutions of a totally different nature.

Nevertheless, it is striking that the regime for the compensation of occupational diseases in Belgium is hardly the subject of serious debate. See Rauws, 2001, pp. 119-122.

See inter alia on environmental damage insurance, Faure, 2002a, pp. 283-328 and Faure, 2002a, pp. $31-41$.

See, inter alia, Elzas, 1998, p. 2 et seq.

See in this respect Kamp, 1996, pp. 36-37; see also Ruers, 1997, p. 1174. See also Faure and Hartlief, 2002, p. 255 et seq. and Faure and Hartlief, 2001, pp. 77-107.

Extra garantieregeling beroepsziekten (EGB). 
These first-party insurance schemes that cover the consequences of occupational hazards already exist in many European systems. They are the so-called special social insurance schemes for occupational accidents and diseases that exist in several countries, including Belgium, France, Germany and the UK. Those legal systems that rely on traditional social security in combination with liability (insurance) benefits are heavily debated. That is why it pays to analyse these arrangements from an economic perspective in more detail.

Whether such a first-party insurance scheme can be considered to be an efficient alternative for third-party liability cannot be answered in general terms. It depends to a significant extent on the details of the proposal and, in particular, on the question of whether the first-party insurance is combined with the employer's liability or not. The underlying principle in a first-party insurance is that - in principle - the insurance pays as soon as damage occurs, provided that the victim can prove that his damage has been caused by the insured risk, irrespective of whether there is liability of a third party (the employer). The advantage of first-party insurance is that the transaction costs are relatively low and risk differentiation is a lot easier. ${ }^{90}$ The reason is simply that the insurer covers the risk of the insured directly. It is much easier for the insured to signal their particular circumstances to the insurer than with liability insurance. A problem with traditional liability insurance is the fact that the insurer insures the risk that his insured (the employer) will harm a victim (the employee) whose properties are unknown ex ante to the insurer. Under first party insurance, the insurer, in principle, directly covers the damage of the victim. In this respect, it is important to make clear that first party insurance is literally the insurance through which the first party (the victim) takes insurance coverage himself. Accident insurances are examples of true first-party insurances. The employers' insurance for occupational diseases, referred to above, is a so-called direct insurance. The victims themselves (the employees) do not conclude the insurance contract but the employer takes on the coverage for the benefit of his employees. They can directly call on the coverage and the system is often referred to as 'direct' insurance.

\subsection{A SHIFT TOWARDS FIRST-PARTY COVER?}

The first-party insurance, which is now proposed in the Netherlands, is not a traditional for, of insurance, since this would mean that the employee would himself take out insurance coverage without any involvement the employer. It is more direct insurance, meaning that the employer takes insurance coverage on behalf of his employees who can directly claim on the basis of the policy. A crucial question in this respect is obviously the relationship with liability law. The ideas put forward in the Netherlands tend to endorse a replacement of the liability system in case compulsory

$\overline{90 \quad \text { See Priest, } 1987}$, pp. 1521-1590. 
direct insurance (e.g., for occupational health) is introduced. Thus, it would amount to a system of partial immunity for employers' liability, but there would be a duty of employers to purchase direct insurance for employees.

Such a scheme can, in principle, have advantages for both parties. We already mentioned that employees complain about lengthy court procedures and uncertain outcomes, whereas employers and their insurers also dislike these uncertainties, since they endanger the predictability of the risk. These uncertainties can, to some extent, be remedied in a system in which the liability issue no longer has to be solved since the insurer of the employer obliges himself to cover the personal injury of employees who becomes victims of occupational diseases. Hence, in such a direct insurance scheme, the insurer only has to calculate the probability that occupational diseases might occur to victims of a certain employer: the question of whether an employer can be held liable for an occupational disease becomes irrelevant. However, a question that still has to be settled is whether the personal injury suffered by the victim is actually caused by an occupational disease. This question is obviously important because insurance should only cover so-called 'risques professionnels'. Therefore causation questions can not be totally avoided.

Another issue, which still has to be settled, is how to give employers incentives for preventing occupational diseases without incurring the deterrent effects of the tort system. Many have warned that no-fault schemes without liability may dilute the incentives for care. ${ }^{91}$ In this respect, policy will have to rely totally upon intensive safety regulations.

\subsection{PREVENTION}

How should this move towards a direct insurance scheme be evaluated from the perspective of optimal prevention and compensation? It is argued, in the literature, that first and direct insurance schemes are better able to provide an optimal differentiation of risks than liability insurance. In principle those advantages can play a role in the case of occupational diseases as well. It would effectively mean that insurers (or social insurance carriers) would differentiate risks between employers. This would effectively mean that, depending upon the preventive measures that are taken and the risks to which an employer exposes his employees, risk differentiation would be applied. Depending upon the effectiveness of risk differentiation among employers, such a system of direct insurance could, in principle, assist in preventing occupational diseases.

One can still question, as indicated above, whether tort law has an additional role to play in such a direct insurance scheme. In countries where these schemes exist (e.g. Belgium for industrial accidents), employers' liability is effectively excluded. It can

91 This argument was presented, inter alia, by Wansink, 2000, pp. 419-421. 
only be applied in the case of gross negligence or intent by the employer. In practice, these cases are rare, so that employers' liability basically plays no additional role. In the Netherlands, the fear exists today that, if employers' liability were entirely replaced by a system of direct insurance, incentives for the prevention of employers would be lost. Whether that is of course the case remains an empirical issue.

\subsection{COMPENSATION}

A similar debate is taking place about whether a direct insurance scheme can lead to optimal compensation. First, the question of whether this would merely be a voluntary scheme or whether there would be compulsory insurance has to be asked. In the case of a voluntary scheme, victims would be dependant on the employer for covering the risk and compensation would not be guaranteed. Again, the Belgian example makes it clear that if one wishes to provide guaranteed compensation for victims, introducing mandatory coverage may be indicated. Whether the compensation is optimal depends on the amounts provided. Lump-sum compensation corresponding with the lost income is usually provided. Compensation for pain and suffering is (for example in Belgium) not included in the lump sum payment of the compulsory insurance scheme for industrial accidents. Compensation under a direct insurance scheme is. in that sense, lower than under tort law. Here one again confronts the basic choice between: payments under a direct insurance scheme have a low threshold but are limited in amount compared to the 'luxury' of the tort law system. Of course, the question of whether the amounts provided in the new Dutch scheme will merely compensate for lost income or will contain an element of compensation for pain and suffering, will be an important element in the decision of whether or not to incorporate such a scheme.

As mentioned above, there are many examples of social insurance schemes for occupational accidents and diseases that provide higher compensation than merely for the basic needs and even include some compensation for non-pecuniary losses (usually through lump sum payments). This shows that these systems can provide a level of compensation which can hold the middle between the coverage of the basic needs under traditional social security and the full compensation under tort law.

\subsection{PRACTICE}

Such a direct insurance scheme already exists, as already noted, in Belgium ${ }^{92}$ and in many other legal systems.. However, in Belgium it does not apply to occupational diseases, but only to industrial accidents. The system is mandatory and provides (limited) benefits to compensate inter alia lost income. The compensation is guaranteed

$92 \quad$ Rauws, 2001, pp. 111-118. 
through mandatory coverage, but the amounts awarded are, of course, less than in tort law. Since insurance is provided through the commercial market, insurers can differentiate risks by requiring additional safety measures and adapting the premium to the risks. Employers are, however, no longer exposed to tort law, except for cases of intent. ${ }^{93}$ Whether the system (more particularly the risk differentiation by insurers) provides sufficient incentives for prevention has not yet been empirically tested. In addition, many of the American workmen's compensation schemes are direct insurance schemes in the sense discussed above: the employer is held liable for part of the injured workers' accident costs and is legally compelled to purchase insurance. Most workmen's compensation schemes are risk rated in the sense that premium costs are linked to the firm's industrial accident experience. ${ }^{94}$

\subsection{EMPIRICAL EVIDENCE}

A weakness of the approach presented so far is that many of the advantages and disadvantages of various compensation systems for occupational diseases that are identified are only identified theoretically. Some indications of possible preventive effects are given, based on assumptions about the effects of particular legal rules (liability, insurance, social security payments) on behaviour. The important question is whether there is any proof that, for example, employers will actually change their behaviour and pay more attention to the prevention of occupational diseases, for example when they are more exposed to liability. Intuitively one can assume that, when an actor (like an employer) has to bear the financial consequences, this will affect the actor's behaviour. The question remains of whether there is any empirical evidence to back-up these assumed effects.

There is some empirical literature, although much of it is already outdated and most of it is of American origin. The results are therefore not easily transferable to other legal systems, like in those in Asia or in Western Europe. There is also some empirical evidence, e.g. on the effects of liability rules versus regulation, but there is less information for example on the comparative advantage of a direct insurance scheme compared to liability insurance or social security mechanisms. It is in this respect striking that governments often introduce measures on the basis of their assumed effects, when there is neither ex ante nor ex post any empirical data available to examine the reliability of these assumptions. ${ }^{95}$

\footnotetext{
$93 \quad$ Ibid, pp. 114-118.

94 See Oi, 1973-74, p. 692.

95 See in this respect the comment by Oi: 'The lack of reliable and relevant injury statistics that would enable us to describe and analyze the industrial safety problem was one of the major concerns in the hearings preceding the establishment of OSHA' (Oi, 1973-74, p. 695).
} 
For example, in some frequently-cited research, Chelius showed that the number of occupational diseases dropped in the US after the introduction of strict liability. ${ }^{96}$ Nevertheless, one has to be careful about the interpretation of such results. First. they were achieved within a typical American context. Thus, it may be that the influence of regulation was less. In this respect, if one relies primarily on liability rules for safety at work, one should not be surprised that an improvement in prevention can be realised with a shift from negligence towards strict liability. Later research has been quite critical of the results presented by Chelius. Ten years later, Fishback argued that the introduction of strict liability in the American wine industry led to an increase of the number of accidents at work. ${ }^{97}$ Fishback argued that Chelius used wrong data. The increase in the number of industrial accidents would be caused through moral hazard. The move to strict liability (without contributory negligence) would have led to less care on the part of employees who would be fully compensated. The decreased care of the employees would not be outweighed by the additional preventive efforts by the employer as a result of the introduction of strict liability. ${ }^{98}$

There is also interesting empirical evidence as far as the choice between liability rules and regulation to promote safety at work is concerned. This literature clearly holds that regulation of safety at work is necessary as a correction of market failure, more particularly because of the lack of information on the part of the employee. ${ }^{99}$ Empirical research, e.g. by Viscusi, shows that regulation by the American Occupational Safety and Health Administration (OSHA) had a statistically significant positive affect on sickness leave following accidents at work. ${ }^{100}$ Additionally, Dewees examined the effectiveness of liability rules as far as the prevention of occupational diseases is concerned. After the presentation of empirical research, Dewees argued that

'This paper has shown the ineffectiveness of imposing tort liability as an incentive to control worker exposure to toxic materials causing disease of long latency'. ${ }^{101}$

This empirical research shows that, not withstanding the enforcement problems with regulation, OSHA had a positive influence although the liability rules had little effect on preventing occupational diseases. This is in line with the theoretical literature mentioned above. ${ }^{102}$

\footnotetext{
96 Chelius, 1974, pp. 293-309.

97 Fishback, 1987, pp. 305-328.

$98 \quad$ Ibid, pp. 324-325.

99 See Rea, 1981, pp. 80-93.

100 Viscusi, 1986, pp. 567-580: OSHA Inspections may have a significant effect on work plus safety that occurs with one-year lag'.

101 Dewees, 1986, p. 319.

102 For further empirical evidence on industrial safety (with respect to accidents at work) in the U.S. see Oi, 1973-1974, pp. 680-691.
} 
Philipsen recently summarised the empirical evidence on prevention and compensation for work injuries in the United States and in Europe. ${ }^{103}$ He quotes inter alia a study by Dewees, Duff and Trebilcock who argue that the tort system 'performs so poorly in compensating most victims of personal injury that we should abandon it as a means of pursuing this compensation objective, turning instead to other instruments'. They also argue that the deterrent effect of tort is limited and uneven or cannot be established by existing empirical studies. ${ }^{104}$ Philipsen also quotes a few studies that analyse the influence of the American system of workers' compensation on the prevention of work related injuries. Moore and Viscusi argue that workers' compensation 'is a driving force in reducing fatalities at the work place'. They argue that, without workers' compensation, industrial fatality risks could have risen by more than 40 per cent. Thus, they conclude that workers' compensation has had a considerable deterrent effect. ${ }^{105}$ Some interesting evidence is also provided concerning the German work place compensation scheme in the sugar industry. After it introduced a risk-rated premium, this apparently induced managers to take measures aimed at accident prevention. The result was thus that the accident rate dropped. ${ }^{106}$ In general, there is far less empirical material concerning the effects of compensation mechanisms on prevention in Europe than in the US. ${ }^{107}$

\section{CONCLUDING OBSERVATIONS}

The goal of this paper was to show that the economic analysis of law can provide a useful contribution to thinking about optimal compensation mechanisms for occupation diseases. The economic analysis of law forces us to ask a number of relevant questions. Indeed, as we pointed out in the introduction to the paper, the economic analysis of law distinguishes between the prevention and compensation goals of legal rules. Economists argue that the financing structure of a compensation mechanism may have important effects for both prevention and for compensation. For an economist, prevention is almost more important than compensation. Legal rules should thus primarily aim at prevention, not necessarily of all accidents, but at least of those accidents that are worth preventing on economic grounds. ${ }^{108}$ Economists pay a

\footnotetext{
103 Philipsen, 2006a, to be published and Philipsen, 2006b.

104 See Dewees, Duff and Trebilcock, 1996, p. 412.

105 See Moore and Viscusi, 1990.

106 See Kötz and Schäfer, 1993, p. 19 and following.

107 See, for example, the contribution of Suarez Serrano and Loredo Fernandez quoted above (footnote 72) and the overview of research provided in the papers by Philipsen referred to above.

108 The economic goal is to provide incentives to the market participants (employers and employees) to take optimal care to reduce the risk of occupational diseases, optimal care being defined as care of which the marginal costs equal the marginal benefits in further reduction of the risk.
} 
lot of attention to instruments that can achieve prevention. However, the central focus of this paper stressed that, according to the economic criteria for safety regulation, occupational diseases should primarily be prevented through regulation. Given the fact that there is a latency risk (occupational diseases often have a 'long-tail'), potential causation problems and an insolvency risk, liability rules will not sufficiently prevent occupational diseases. Liability rules can at best play a secondary role to back up for regulatory failure. As far as compensation is concerned, it was made clear that liability rules can only be of limited importance since the employee would have to meet high and serious thresholds before employers' liability for occupational diseases can be accepted. It is therefore considered by some as a 'luxury system'. It is also held that given the insolvency risk, liability rules can only provide compensation (if at all) if they are backed up by (compulsory) liability insurance. However, in most legal systems (although there are of course substantial differences) the compensation for basic needs after an occupational disease takes place (sometimes referred to as the 'Existenzsicherung') is often achieved through social security. The differences with tort law are well documented: whereas tort law has high thresholds and can provide a guarantee of full compensation when its stringent conditions are met, most social security systems will be more lenient as far as the conditions for intervention are concerned. They will never provide a guarantee of full compensation to the employee who was victimised as a result of an occupational disease. Additionally, empirical research has demonstrated that tort law in practice only plays a minor role in compensating for personal injury.

It is particularly because of the limited compensation provided by social security that, in some systems, victims attempt to use the tort system to obtain compensation of the part of the damage that is not covered under social security. In legal systems where liability suits against employers are still allowed (like those in the UK and in the Netherlands), it is clear that employers' liability for occupational diseases causes problems at the level of insurability. The 'long-tail' characteristics of an occupational disease and uncertainties in case law have caused some liability insurers to withdraw from the market of covering occupational diseases. That is why alternative compensation mechanisms, e.g. compensation funds and different types of insurance, in particular first party or direct insurance schemes, are examined. In some systems (for instance the coverage for industrial accidents in Belgium), direct insurance by the employers for the benefit of employees exists within the social security scheme. This shows that there are, on the one hand, thin lines between social security and private insurance. In some cases, a similar arrangement (like direct insurance) could be provided either through private insurance or through social security. ${ }^{109}$ On the other hand, it shows that compensation for occupational diseases, whether private or public

109 The Belgian compulsory employers' liability insurance is formally a part of social security, although provided through private insurers (see Faure and Hartlief, 2001, pp. 100-103). 
in nature, can take a variety of different forms. Economists would, however, argue that no matter what compensation mechanism is chosen, the financing should in principle be such that risk-related premiums are demanded from employers. This corresponds with the basic economic assumption that risk-based premiums will provide better incentives to employers for the prevention of occupational diseases. In that respect the Belgian system cannot only be applauded. While there is a direct insurance scheme for industrial accidents with risk-related premiums charged by commercial insurers, this is not the case for occupational diseases. Victims are compensated through a government-operated fund, which is financed through levies, which are not risk based at all.

A large part of the literature dealt with in this paper was of a theoretical nature. However, there is also some 'modest' empirical research, which backs up some of the theoretical findings. Within the scope of this paper, we were only able to provide a few illustrations. Nevertheless, the important conclusions, which are backed up by empirical literature, are rather interesting:

1. It seems that regulation has been instrumental in preventing injuries at work;

2. Liability rules do not seem to have any preventive affect as far as occupational diseases are concerned. Both findings thus confirm the theoretical statement that occupational diseases can better be prevented through regulation than through liability rules;

3. Financing schemes that are risk related (like the example of the German sugar industry) seem to be able to provide correct incentives to employers to prevent occupational diseases. Such a risk differentiation is inter alia, possible in direct insurance schemes and in other risk related financing mechanisms, like workmen's compensation.

Of course, in this paper law and economics was merely used as an instrument to show some advantages or potential disadvantages of different models that could be used to compensate for occupational diseases. Many aspects could not be dealt with. For instance, there are obviously relationships between the various models, including insurance, social security and liability through the right of recourse. Moreover, in many cases there is not just one instrument aiming at prevention (regulation) and another aiming at compensation (social security). In practice, a mix of different instruments is used aiming both at prevention and at compensation of occupational diseases.

Some empirical research was cited to back up theoretical assumptions from the literature. However, still too often legislators seem to take important policy decisions based on assumptions about the particular effects of certain mechanisms. It is important that, far more than is the case today, empirical research to examine the effects of particular policy instruments, both for the prevention and for the compensation of 
occupational diseases, should be encouraged by governments. If there is one lesson from the economic literature, it should be a strong recommendation to the legislators to develop serious initiatives towards data collection. The result will hopefully be that, in the future, not only ex ante expectations on assumed affects of policy instruments will be based on data, but ex post it will be possible to test whether policy instruments chosen by legislators could actually lead to better prevention and compensation for occupational diseases.

\section{REFERENCES}

Aвraham, K.S. (1982), 'Cost Internalisation, Insurance, and Toxic Tort Compensation Funds', Virginia Journal of Natural Resource, 2, 123-131.

Abraham, K. (1988), 'Environmental Liability and the Limits of Insurance', Columbia Law Review, 88, 949-951.

Adnett, N. and Dawson, A. (1988), 'The Economic Analysis of Industrial Accidents:

A Reassessment', International Review of Applied Economics, 12, 241-256.

Bloembergen, A.R. (1980), 'De invloed van verzekeringen' in Schade lijden en schade dragen, 16-17.

Bolt, A.T., Spier, J. and HaAzen, O.A. (1996), De uitdijende reikwijdte van de aansprakelijkheid uit onrechtmatige daad, Zwolle, Tjeenk Willink.

Calabresi, G. (1970), The Costs of Accidents: A Legal and Economic Analysis, New Haven, Yale University Press.

Center of Competence for Workers (2005), Compensation, Economic Incentives.

A Reflection on Workers' Compensation Systems, München, Munich Reinsurance Group, November.

Chelius, J.R. (1973-74), 'The Control of Industrial Accidents: Economic Theory and Empirical Evidence', Law and Contemporary Problems, 38, 700-729.

Chelius, J. (1974), 'Liability for Industrial Accidents: A Comparison of Negligence and Strict Liability Systems', Journal of Legal Studies, 293-309.

Danzon, P.M. (1987), 'Compensation for Occupational Diseases: Evaluating the Options', The Journal of Risk and Insurance, 54, 263-282.

Dewees, D. (1986), 'Economic Incentives for Controlling Industrial Disease: The Asbestos Case', Journal of Legal Studies, 289-319.

Dewees, D., Duff, D. and Trebilcock, M. (1996), Exploring the Domain of Accident Law: Taking the Facts Seriously, Oxford, Oxford University Press.

Dommering-VAn Rongen, L. (1996), 'Een schadefonds voor asbestslachtoffers', Tijdschrift voor milieuaansprakelijkheid, 96 et seq.

Dijkshoorn, M.W. (1996), 'Ontwikkelingen in de WAO', Verzekeringsarchief, 73, 8286. 
Elzas, R.P.H. (1998), 'Personenschade: enkele ontwikkelingen en suggesties', Verzekeringsarchief, 2 et seq.

Faure, M. and Van Den Bergh, R. (1993), 'Het toelaten van kartels op de Europese verzekeringsmarkt: hogere premies, lagere kwaliteit en meer ongevallen?', Nederlands Juristenblad, 261-267.

Faure, M. and Van Den Bergh, R. (1995), 'Restrictions of Competition on Insurance Markets and the Applicability of EEC Antitrust Law', Kyklos, 65-85.

Faure, M. and Hartlief, T. (1996a), 'Compensation Funds Versus Liability and Insurance For Remedying Environmental Damage', Review of European Community and International Environmental Law, 321-326.

Faure, M. and Hartlief, T. (1996b), 'Een asbestfonds als alternatief voor de aansprakelijkheid van de werkgever?', Tijdschrift voor sociaal recht, 37-43.

Faure, M. (1998), 'The Applicability of the Principles of Private Insurance to Social Healthcare Insurance Seen from a Law and Economics Perspective', The Geneva Papers on Risk and Insurance, 265-293.

Faure, M. and Hartlief, T. (1998a), 'Verzekering en financiering van beroepsziekten: Enkele tips voor de SER', Nederlands Juristenblad, 1139.

Faure, M. and Hartlief, T. (1998b), 'Een schadefonds als alternatief voor aansprakelijkheid en verzekering?', Rechtsgeleerd magazijn Themis, 211-228.

Faure, M. and Hartlief, T. (2001), 'Directe schadeverzekering bij beroepsziekten als alternatief voor aansprakelijkheid en verzekeringen', in FAURE, M. and Hartlief, T. (eds.), Schade door arbeidsongevallen en nieuwe beroepsziekten, Den Haag, Boom Juridische Uitgevers, 77-107.

Faure, M. (2002a), 'Environmental Damage Insurance in the Netherlands', Environmental Liability, 31-41.

Faure, M. (2002b), 'Environmental Damage Insurance in Theory and Practice', in Swanson, T. (ed.), An Introduction to the Law and Economics of Environmental Policy: Issues in Institutional Design, JAI Press, 283-328.

Faure, M. (2002c), 'Strict Liability. Economic Analysis' in Koch, B.A. and KozIol, H. (eds.), Unification of Tort Law: Strict Liability, Vienna, Springer, 361-394.

Faure, M. and Hartlief, T. (2002), Nieuwe risico's en vragen van aansprakelijkheid en verzekering, Deventer, Kluwer, 255.

Faure, M. and Hartlief, T. (2003a), 'Economic Analysis', in Magnus, U. (ed.), The Impact of Social Security Law on Tort Law, Vienna, Springer, 222-265.

Faure, M. and Hartlief, T. (2003b), 'Social Security versus Tort Law As Instruments to Compensate Personal Injuries: A Dutch Law and Economics Perspective', in Magnus, U. (ed.), Social Law versus Tort Law, Vienna, ECTIL, 253-255.

Faure, M. and Hartlief, T. (2003c), Insurance and Expanding Systemic Risks, Paris, OECD.

Ferejohn, J. and Shipan, Ch. (1990), 'Congressional Influence on Bureaucracy', Journal of Law, Economics \& Organization, 6, 1-20. 
Fishback, P. (1987), 'Liability Rules and Accident Prevention in the Work Place: Empirical Evidence from the Early Twentieth Century', Journal of Legal Studies, 305-328.

Frank, R. (1997), 'Lessons from the Great Battle: Health Care Reform, 1992-1994', Arch. Phys. Med. Rehabil., 122-123.

Frenk, N. (1997), 'Asbestslachtoffers', Verkeersrecht, 295-298.

Fuchs, V. (1976), 'From Bismarck to Woodcock: The 'Irrational' Pursuit of National Health Insurance', Journal of Law and Economics, 347-359.

HARTLIEF, T. (1997), Ieder draagt zijn eigen schade.

Hoop, R.I.R. (2007), 'Shift in Work-related Injuries: An Explanatory Analysis', in Hartlief, T. and Klosse, S. (eds.), Shift in Compensating Work-related Injuries and Diseases, Vienna, Springer, forthcoming.

Hustinx, J.P. and Stolker, C.J.J.M. (1997), 'Massaschade en fondsvorming', Verzekeringsarchief, 58 et seq.

Johnson, W. (1977), 'Choice of Compulsory Insurance under Adverse Selection', Public Choice, 23-25.

Jost, P.J. (1996), 'Limited liability and the requirement to purchase insurance', International Review of Law and Economics, 259-276.

Kaмp, P.A.J. (1996), 'Verslag vergadering over de uitdijende reikwijdte van de aansprakelijkheid uit onrechtmatige daad', in Handelingen Nederlandse Juristenvereniging II, 36-37.

Katzman, M.T. (1988), 'Pollution Liability Insurance and Catastrophic Environmental Risk', Journal of Risk and Insurance, 75-100.

KLosse, S. (2000), 'Schadeleer: geschikt fundament voor sociale zekerheid in de $21^{\mathrm{e}}$ eeuw?', in Klosse, S. and Berghman, J. (ed.), Sociale zekerheid: een ander gezichtspunt. Toekomstperspectief vanuit vier disciplines, Brugge, die Keure.

Klosse, S. and Vonk, G. (2000), 'De betekenis van het recht voor de toekomst van de sociale zekerheid', in KLosse, S. (ed.), Sociale zekerheid: een ander gezichtspunt, op. cit., 196-217.

Kötz, H. and Schäfer, H. (1993), 'Economic Incentives to Accident Prevention: An Empirical Study of the German Sugar Industry', International Review of Law and Economics, 19 et seq.

KozIol, H. (1997a), Österreichisches Haftpflichtrecht, Band I, Allgemeiner Teil, $3^{\text {rd }}$ ed., $8-13$.

Koziol, H. (1997b), 'Die Arzthaftung im geltenden und künftigen Recht', Haftungsrechtliche Perspektiven der ärztlichen Behandlung, Linz Universitatsverlag Rudolf Trauner, 21-35.

Kunreuther, H., Hogarth, R. and Meszaros, J. (1993), 'Insurer Ambiguity and Market Failure', Journal of Risk and Uncertainty, 71-87. 
Le BlanC, L.J.C.M. (1990), 'Bismarck als benchmark. Enkele rechtseconomische beschouwingen over publieke sector en sociale zekerheid in Nederland', Ars Aequi, 654-659.

Mitchell, O. and Zeldes, S. (1996), Social Security Privatisation: A Structure for Analysis, Nashville, American Economic Review, 363-367.

Moore, M.J. and Viscusi, W.K. (1990), Compensation Mechanisms for Job Risks: Wages, Workers' Compensation, and Product Liability, Princeton, Princeton University.

Ogus, A.I. (2007),'Shifts in Governance for Compensation to Damage: A Framework for Analysis', in Van Boom, W.H. and Faure, M.G. (eds.), Shifts in Compensation between Private and Public Systems, Vienna, Springer, forthcoming.

Oi, W.Y. (1973-74), 'On the Economics of Industrial Safety', Law and Contemporary Problems, 38, 669-699.

Pauly, M. (1974), 'Overinsurance and the Public Provision of Insurance: The Roles of Moral Hazard and Adverse Selection', Quarterly Journal of Economics, 44-62.

PAuly, M. (1988), 'Competition in Health Insurance Markets', Law and Contemporary Problems, 237-271.

Philipsen, N.J. (2006a), 'Prevention and Compensation of Work Injury in the United States. An Overview of Existing Empirical Evidence', paper composed within the framework of the 'Shifts in Governance' project, 12 May 2006, to be published.

Philipsen, N.J. (2006b), 'Industrial Accidents and Occupational Diseases: Some Empirical Findings for the Netherlands, Belgium, Germany and Great Britain', paper composed within the framework of the 'Shifts in Governance' project, 9 May.

Pieters, D. (1993a), Introduction in the Basic Principles of Social Security, The Hague, Kluwer Law International.

Pieters, D. (ed.) (1993b), Introduction into the Social Security Law of the Member States of the European Community, $2^{\text {nd }}$ edition, Antwerp, Maklu.

Polborn, M. (1998), 'Mandatory insurance and the judgment-proof problem', International Review of Law and Economics, 141-146.

Priest, G. (1987), 'The Current Insurance Crisis and Modern Tort Law', Yale Law Journal, 1521-1590.

Rauws, W. (2001), 'Financiering van schade veroorzaakt door arbeidsongevallen en (nieuwe) beroepsziekten: België als wenkend voorbeeld?', in FAURE, M. and Hartlief, T. (eds.), Schade door arbeidsongevallen en nieuwe beroepsziekten, Den Haag, Boom, 109-129.

REA, S. (1981), 'Workmen's Compensation and Occupational Safety under Imperfect Information', American Economic Review, 80-93.

Rose-Ackerman, S. (1991), 'Regulation and the Law of Torts', American Economic Review, Papers and Proceedings, 54-58. 
Rothschild, M. and Stiglitz, J. (1976), 'Equilibrium in Competitive Insurance Markets: An Essay on the Economics of Imperfect Information', Quarterly Journal of Economics, 629-649.

RuERs, R.F. (1997), Nederlands Juristenblad, 1174.

Schwartz, G. (1997), 'Mixed Theories of Tort Law: Affirming Both Deterrence and Corrective Justice', Texas Law Review, 75, 1804-1834.

Shavell, S. (1979), 'On Moral Hazard and Insurance', Quarterly Journal of Economics, 541-562.

Shavell, S. (1980), 'Strict Liability versus Negligence', Journal of Legal Studies, 1-25.

Shavell, S. (1984a), 'Liability for Harm versus Regulation of Safety', Journal of Legal Studies, 357-374.

Shavell, S. (1984b), 'A model of the Optimal use of Liability and Safety Regulation', Rand Journal of Economics, 271-280.

Shavell, S. (1986), 'The judgment-proof problem', International Review of Law of Economics, 43-58.

Shavell, S. (1987), Economic Analysis of Accident Law, Cambridge, Harvard University Press.

Sкоgн, G. (1982), 'Public Insurance and Accident Prevention', The International Review of Law and Economics, 2, 67-80.

Skogh, G. (1989), 'The Combination of Private and Public Regulation of Safety', in Faure, M. and Van den Bergh, R. (eds.), Essays in Law and Economics. Corporations, Accident Prevention and Compensation for Losses, Antwerp, Maklu, 87-101.

Skogh, G. (2000), 'Mandatory insurance: transaction costs analysis of insurance', in Bouckaert, B. and De Geest, G. (eds.), Encyclopedia of Law and Economics, Cheltenham, Edward Elgar, 521-537.

SpIEr, J. (ed.) (1996), The Limits of Liability, Keeping the Floodgates Shut, The Hague, Kluwer Law International.

Spier, J. and HAAzen, O. (1996), 'Amerikaanse toestanden en de nieuwe aansprakelijkheidsverzekering voor bedrijven en beroepen', Nederlands Juristenblad, 45-50.

Suarez Serrano, E. and Loredo Fernandez, E. (2001), 'Organizational Alternatives for Companies' Management of Occupational Risks: The Examples of Spain and Argentina', International Social Security Review, 54, 41-57.

Van De Griendt, W. (1995), 'De Amerikaanse Paradox', Sociaal bestek (7/8), 9-12.

VAn Kessel, J. (2000), 'Schade bij werknemers: aandachtspunten voor deze eeuw. Betere werking van het huidige stelsel door nauwere afstemming op schadeleer, meer flexibiliteit en verdergaande integratie', in KLosse, S. (ed.), Sociale zekerheid: een ander gezichtspunt. Toekomstperspectief vanuit vier disciplines, Brugge, die Keure, 257-260. 
VAn LANGendonck, J. (1988), 'Arbeidsongevallen en aansprakelijkheid', Tijdschrift voor Sociaal Recht, special issue, 1, 73-88.

Van Mierlo, J.G.A. (1991), 'Een alternatief voor het Plan-Simons? Overwegingen vanuit de welvaartstheorie', ESB, 1164.

Van Wijngaarden, P.J., Van Den Heuvel, F.G. and Vrooman, J.C. (eds.) (1992), Preventie in de sociale zekerheid, Den Haag, VUGA.

VIscusi, W.L. (1986), 'The Impact of Occupational Safety and Health Regulation, 1973-1983', Rand Journal of Economics, 567-580.

WAnsink, J.H. (2000), 'Onverzekerbare aansprakelijkheid: (verplichte) directe verzekeringen. Een aanvaardbaar alternatief?', in Hartlief, T. and Mendel, M.M. (eds.), Verzekering en maatschappij, Deventer, Kluwer, 419-421.

Whinston, M. (1983), 'Moral Hazard, Adverse Selection and the Optimal Provision of Social Insurance', Journal of Public Economics, 49-71.

Woertmann M.J.A.L. (1995), 'Employers' Liability for diseases caused by asbestos in the Netherlands and the United States of America', in VAn Delft-BAAs, M. and Hondius, E.H. (eds.), Jaarboek Konsumentenrecht, Deventer, Kluwer, 155-182. 